\title{
Peter Beresford
}

University of Essex, United Kingdom

\section{SERVICE USER INVOLVEMENT IN SOCIAL WORK AND BEYOND. EXPLORING ITS ORIGINS AND DESTINATIONS}

\begin{abstract}
This article offers a critical analysis of service user involvement in social work by exploring the modern history of its development. It does this by examining: a) the increasing pressures for more democratic politics and societies during the course of the twentieth century, making connections between efforts to widen suffrage and extend individual and collective rights; the development of representative and participatory democracy and, the emergence of new social movements, including those based on identity and relations with welfare, and b) the impacts on and relations of these with social work. It charts four key stages in the development of user involvement in social work specifically and public policy more generally, exploring by reference to the UK as a case study and international experience, both obstacles in the way of inclusive and effective user involvement and ways in which it seems to be being advanced more effectively.
\end{abstract}

Key words: user involvement, democratization, new social movements, empowerment, history, social work

\section{Introduction}

There are now requirements for user and carer involvement in social work in some countries and provisions for it in many more. While we cannot really describe it as a global movement, it is certainly an international one. While its development can be said to be patchy both within countries and across them, it is nonetheless widespread. In some senses, as we shall see, participation, can be said to be an inherent part of social work, but it has also emerged as a distinct and innovative strand in it. This pressure for user involvement reflects values and commitments within social work itself, some at its very heart. But it also reflects much broader developments and ideas and the timing and nature of its expansion relate to these too. It did not come out of nowhere. Instead it reflects much bigger political, ideological, cultural, social and personal changes. In this discussion I will try and unpack these complex interactions, both because of their importance for understanding this development, but also because doing so is likely to help us take It forward more effectively and challenge difficulties and barriers in its way.

The issue of user involvement in social work has a surprisingly short history, yet it has emerged as of central and increasing importance, for both social work and for 
participation itself. The aim of this paper is to put this development both in the context of social work and of participatory developments more generally. While it will draw especially on UK experience, where particular progress has been identified, it will also explore international ideas and experience.

There is often a tendency to treat what might be described as 'feel-good' ideas like 'community', 'self-help', and indeed 'user involvement', separately from their broader social, political, ideological and cultural relations, rather than to treat them with the same critical and investigative rigour that might be judged appropriate for other more mainstream concerns like finance, workforce and management. This may also be an indicator of the lesser seriousness and priority with that such issues tend to be accorded, as if they were peripheral or 'add-on' concerns. Such an approach seems increasingly at odds with the centrality currently invested in participatory approaches to policy and practice. For this reason, I have adopted an historical lense to try and make sense of user involvement in social work in this discussion. It allows us not only to put it in historical context and make better sense of its origins, relations and development. It is also likely to help us avoid the tendency to 'reify' participatory developments and treat them in a narrow technicist way, instead of exploring and unpacking their ideological, philosophical, policy and professional ramifications, problems and possibilities. The aim here is to try and offer just such an overview of developments and progress in this field which can be helpful to different stakeholders interested in understanding and advancing both the theory and practice of participation, exploring both the barriers and opportunities that they may face.

More often the approach to undertaking and advancing 'user involvement' has been one based on the production of abstracted 'how to do it' guides and related to this, the creation of models for involvement. One of the earliest and still one of the most often cited is Arnstein's 'Ladder of Citizen Participation' (Arnstein 1969). This offered a typology of involvement from 'manipulation' (non-participation) at the bottom, through consultation (tokenism), to 'citizen control' at the top (citizen power). The problem with such uni-dimensional approaches to participation is that while in some cases recognizing power differences, they still struggle to address its essentially political nature. As a result such models tend to be reductionist, over-simplifying and ill-suited to dealing with the real life complexities and ambiguities of such involvement (Beresford, Croft 1993).

\section{Beginnings?}

The text that is generally identified as the first in UK literature to explore user or client involvement was The Client Speaks, published in 1970. But this was not actually concerned with involving service users, but instead merely turned to them as a data source (Beresford, Croft 1987). A text book on user and carer involvement for social work students suggests that such involvement really only emerged in social work much later. Charting its development, the book largely seems to locate this in the 1990s with 
most references to it appearing from the late 1990s to 2000s (Warren 2007: 32-34). However as the author, Janet Warren observed:

Present-day service user involvement in social work....needs to be understood within the much broader context of the social, cultural, economic and political changes that have impacted on the United Kingdom, mainland Europe and North America over the last 60 years in particular (Warren 2007: 34).

\section{A short history of participation and user involvement}

That is the aim here and this demands at the very least an exploration of the histories of both participation and social work. We begin with political participation.

It is important to remember that for at least the first quarter of the $20^{\text {th }}$ century, while we are talking here about provisions for participatory democracy, many people did not even have voting rights under representative democracy. It is helpful to see this quest for universal suffrage as the first stage of modern movements for a say in society, its institutions and services. It also perhaps constitutes the first of several phases that can be identified as a basis for making sense of the growing pressure for greater participation or user involvement in social work and other policies and services.

These phases shouldn't be seen as narrowly sequential. Overlaps and inconsistencies can be identified. They highlight the need not to isolate or reify developments in participation and user involvement. These have taken place in different ways and at different times and paces in different countries. They may also interact and co-exist with each other in different ways. But the broad phases identified here do nonetheless, I suggest, reflect wider international political and ideological trends.

\section{Phase one: Working for universal suffrage and social rights}

From the vantage point of the early twenty first century, it can still be shocking to be reminded how long it took to achieve universal suffrage even in supposedly 'advanced western democratic societies. Thus it was not until 1918 in the UK that the Representation of the People Act gave women the vote provided they were aged over 30 and either they, or their husband, met a property qualification. It was only in the same year that women were allowed to stand for parliament. Until then, when the property qualification for men was abolished, only about 60 per cent of men had the vote. The rate of change was rapid. In 1900, less than seven million people in the UK had the right to vote. This had risen to more than 21 million, more than half the population by 1918 . However, not until 1928 under the Equal Franchise Act did women in the UK share equal voting rights with men, with fifteen million women now eligible. Internationally, very few nations had introduced provisions for universal adult suffrage until the twentieth century, with 
some still withholding voting rights from indigenous peoples, minority ethnic and other marginalized groups until its second half.

But if the first half of the twentieth century was a time of increasing democratization and the extension of suffrage (with the obvious exceptions of Nazi Germany, Stalinist Soviet Union and Militarised Japan), it was also a time of enormous and growing suffering worldwide. The two world war and international interwar economic depressions, caused enormous problems of want, death, disease, suffering and hunger on a global scale. In a time of increasing political, economic and social uncertainty and inequality, rising pressure for electoral representation came to be coupled internationally with pressure for the achievement of social rights. Such rights are taken to include the right to work, to decent housing, education, adequate income and social security and proper social, health and medical services.

This first major expression of this struggle for 'social citizenship' was the creation of post-second world war welfare states, first in the UK and then other countries. The UK welfare state's proponents saw it as having a key role to play in the protection and promotion of people's economic and social well-being of its citizens. This was articulated by the sociologist T.H. Marshall. He identified the welfare state as a distinctive combination of democracy, welfare, and capitalism, which he saw as protecting people from the instability, harshness and arbitrariness of the market. The welfare state's policy provisions and legislation was seen as compensating for inequalities arising from the market, in contrast to the Poor Law which sought to police and regulate people disadvantaged in society and through the market (Marshall 1950). What such thinking failed to take account of, as subsequent critiques from feminist, black and disability rights perspectives have highlighted, were the inherent biases of such concepts of citizenship which were very much tied to the thinking of their time. From a feminist perspective, work like that of Marshall is of limited value because of its narrow focus on able-bodied men and failure to take account of the social rights of women and barriers to their achievement (Lister 2003). Similarly struggles to equalise political power through efforts to achieve universal suffrage under representative structures of democracy had only limited success in transcending prevailing inequalities on the basis of identity, status and power.

\section{Phase two: Provisions for participatory democracy and community development}

The initial struggle for political and social rights can be seen as leading to the second stage of struggle for further democratisation. In the UK, the beginning of this phase is associated with the 1960s and was linked with the return to power of left of centre Labour governments after years of right of centre Conservative government. There was talk of the 'rediscovery of poverty' in the midst of what was seen as an 'affluent society'. This discovery was associated with major social science academics like Peter Townsend and Brian Abel-Smith, who combined research with activism (Abel-Smith, Townsend 
1965). Post-war 'consensus' between political left and right, that mixed economy welfare states had secured the rights and social security of citizens 'from cradle to grave' was challenged. The social policy theoretician Titmuss and others pointed out that welfare services established to counter-balance inequalities in society were failing to do so and that longstanding inequalities and exclusions remained (Titmuss 1968; Halsey 1972). Public and social services were emerging as having their own problems and limitations as an approach to compensating for structural problems and inequalities.

As rising inequalities, exclusions and regressive redistribution were highlighted, a range of focuses and approaches for change were developed. These centred on concepts of social compensation and community involvement. Community based approaches range from highly structured, state and professionally led schemes operating in localities and around issues, to much more autonomous approaches encouraging independent collective action in the community, developing ideas of 'empowerment' and 'conscientization'. All highlight participation, but there has been a tendency in both towards increasing professionalization and state control (Craig et al. 2011; Ledwith 2016).

Thus the UK state-led community development project (CDP), which ran from the 1960s to late 1970s and the education priorities areas (EPA). Both sought to target help on individuals, groups (including women, young people, Black and minority ethnic groups and poor people) and areas (notably inner city areas') identified as deprived and disadvantaged. All sought to 'involve' the people they were working with, although they were generally professionally led. They aimed to raise people's consciousness, skills and 'cultural capital'. All placed an emphasis on support, out-reach and developmental work, to help make this possible. But all equally came under attack for their ambiguity. Competing strands were identified in the work, some more consensual and some conflict based (CDP 1977; Loney 1983). Local involvement was often limited, tokenistic and paternalistic. Poverty remained a continuing problem and was indisputably linked with persistent (and ultimately worsening) economic and social inequality in British society and institutions (Atkinson 1983).

If involving people was part and parcel of the community development and anti-poverty strategies of this time, it was the central feature of new provisions for state land planning. This movement gained momentum in the late 1960s not least because of the deluge of bad planning with large scale urban redevelopment and, central government's desire to free itself of the burden of innumerable appeals. Its landmarks were a major government report and two town and country planning acts of 1968 and 1971 (Beresford, Beresford 1984: 27). For the first time, the legislation made provision for public participation in planning - both development planning and general planning control. This became a model that attracted international interest. The notion of public participation embodied in the two acts was essentially one of public consultation and appeal. The public was offered the limited chance to disagree with what the local authority offered. Not only was participation limited to reacting to existing plans and proposals, rather than being able to co-create these, but the involvement engendered tended to be very limited. 
One of the abiding problems of modern public participation, as we shall explore later, has been the barriers and restrictions that seem to operate on who actually gets involved. This has been an issue that has been associated with all efforts to involve people. It was rapidly apparent in efforts to involve people in land use planning. These exercises, essentially based on expecting people to respond to invitations to get involved and relying on traditional public meetings and conventional verbal and written skills tend to disadvantage and exclude people on the basis of class, ethnicity, gender, age and disability (Beresford, Beresford 1984). They also tend to put a premium on verbal, writing and other social skills which inherently discriminates against less confident, less assertive, less well educated people. Thus they may actually reinforce inequalities in relation to power and participation, rather than compensate for them.

They also exhibit another major shortcoming, which again is not confined to statutory arrangements for participation in planning. As one commentator, campaigning against redevelopment where he lived, observed early in their development:

Millfield benefitted greatly from the termination of public participation in planning... In Millfield... specific issues connected with the planners' proposals were brought to a moderately successful conclusion (from the residents' point of view) only when the planners' rules were abandoned and the ordinary machinery of local councillor, MP, publicity, public discussion and so forth was utilised (Dennis 1972).

This is an inheritance which participatory initiatives still have to live down. While ostensibly intended to extend democracy, they can actually serve to divert people from the long-fought for provisions for representative democracy, offering no more than a tokenistic dead-end that discourages people from pursuing what may actually be more firmly established and effective structures for representative democracy. This is a much broader issue for arrangements for participation. Both community development approaches and provisions for participation in planning continue to operate internationally, but both continue to be subject to the same difficulties and shortcomings.

\section{Phase three: Provisions for participation in health and social care}

The third phase of interest in participation is more much directly related to social work, health and social care and the groups specifically associated with it. This is the emergence of specific requirements for user involvement in health and social care reform in the 1990s. In England this was associated with the passing of the National Health Service and Community Care Act and its implementation in 1993. There were equivalent developments in all the UK countries and also in European countries and North America. Indeed while timings varied this can be seen as at least an international, if not a global development. What is particularly significant about this phase of interest in participation, is that it had at least two major sources - and that these were very 
different in origin and intent. This is a reminder of both the complexity of pressures towards participation and their ideological relations and also the potential ambiguity of interest in public and user participation.

The two developments associated with this phase of interest in citizen and user participation were first the shift to the right politically and the emergence of the New Political Right from the nineteen seventies (culminating in the emergence of neoliberal ideology) and second, the development of new social movements, whose origins can be seen in the 1960s. These movements included the Black civil rights, women's, the gay and lesbian (later the Lesbian, gay, bisexual, transgender, queer [LGBTQ]) movements, associated with identity, as well as the green/environmental, animal rights and anti-nuclear/peace movements (Jordan, Lent 1999; Todd, Taylor 2004).

The participation offered in UK and other subsequent health and social care reforms offered people the right to comment, complain and to have a say in the management or running of services. This reflected the consumerist/managerialist ideology underpinning such state or service system driven schemes for involvement, with involvement effectively being at the level of market research or consultation. While the right to complaint (for example in the English Children Act [1989] and National Health Service and Community Care Act [1990]), represented an innovation, it only applied when things had already gone wrong and tended to be experienced as an individualising and stressful measure (Beresford, Croft 1993).

If the state based pressure for participation was concerned with listening to people's views, the pressure from new social movements was for political and personal change and their direct involvement and say in making it happen. If traditional social movements took as their starting point economic and material concerns, new social movements highlighted issues of human and civil rights and identity in post-industrial society. In the context of social work and social services this has been most powerfully exemplified by the international disabled people's movement.

The pioneering UK disabled people's movement, for example, challenged traditional understandings of disability, rejected conventional interpretations of it in narrow terms of 'personal tragedy' and instead developed a new social model of disability, which highlighting the discriminatory social responses to impairment which 'disabled' people in society. Disabled campaigners called for a new approach to understanding, policy and provision based on a philosophy of 'independent living' which challenged disabling barriers and supported people with impairments - physical, sensory, or intellectual, to live on as equal terms as possible to non-disabled people (Oliver 1983, 1990; Charlton 1998). They placed an emphasis on people speaking for themselves ('self advocacy'), for collective action to support their empowerment through developing their own 'user led' and disabled people's organisations' and on bringing about broader social and political change. Other emerging movements, like that of older people, people with learning difficulties, people living with HIV/AIDS and mental health service users/survivors framed their demands in similar terms, pressing for a direct say in policies and services affecting them, pressing for their own participation in making change. 
However the shared language of involvement of these two competing and conflicting pressures for participation disguise fundamental differences between them and have blurred and confused the issues. While the emergence of service user movements and development of neoliberalism can be seen as having some common origins; notably a reaction against paternalistic top-down state welfare systems, in many other senses they sit at opposite ends of an ideological spectrum. Pressures for privatisation and a reduced role for the state bear little relation to service users' calls for democratisation and empowerment. The consumerist concerns of the neoliberal state and service system do not sit comfortably with the quest for democratisation and empowerment of service users and their allies. Instead they have left many service users feeling that state led schemes for participation are often tokenistic and ineffectual. They have instead developed their own focuses for involvement, which they see as more effective and productive than the prevailing concern with consultation and 'quality control'.

Key areas which have emerged from service users themselves are user involvement in professional training, learning and education; the development of user led research and knowledge production and the development of user-controlled initiatives and approaches. These have made it possible to:

- Develop the kind of learning and training for social work and related professions consistent with supporting people's rights and needs, informed by and respecting service users' understandings of their identities and worlds (SCIE 2009).

- Challenge the exclusion and marginalisation of their perspectives and experience (Faulkner 2010).

- Advance the evidence base for the social understandings of service users and the issues they experience which them themselves have developed, rather than being tied solely to other people's interpretations and understandings of themselves (Beresford, Croft 2012).

- Develop as service users their own organisations, histories, cultures, collectivities and independent action (Beresford 2016).

- Develop as service users ideas, policy and practice consistent with their own models and philosophies (Campbell, Oliver 1996).

While it is important not to overstate the amount of progress made in advancing user involvement in social work (and indeed in policies and services beyond), it would also be a mistake to under-estimate its achievement internationally. At the same time as has already been indicated, progress has often been slow and its implementation hesitant, patchy and contested. Its history is riven with ambiguities and false trails. The rhetoric about involvement has tended always to be in advance of the reality. Some service users talk about 'consultation fatigue' and being 'all consulted out'. We have perhaps reached a new stage in the development of participation generally and user involvement in social work specifically. This is a time of increasing conflict and challenge over the idea and its implementation, perhaps best framed as a new phase in its development. 


\section{Phase four: Reaction and renewal}

Participatory schemes and initiatives have always included ones rooted in consensus as well as conflict. This has been reflected in the different approaches of different user movements. So, for example, the UK disabled people's movement historically while engaging political structures was initially much more separatist than for example, the UK survivors movement, which tended to have much closer links with and often to be closely located within the service system (Barnes et al. 1999).

For a long time there has been a tendency to overlook or fudge inherent contradictions between different approaches to participation; their different aims and underpinning ideas. Instead their various proponents have sought to advance their own agendas and highlighted the practical rather than ideological problems underlying resulting difficulties. But more recently we seem to be entering a new phase of participation and user involvement, where these differences and difficulties have become more apparent, positions have seemed to become more polarized and entrenched and protagonists have emerged as in greater conflict with each other. Thus, for all the talk of the rights and say of the service consumer, in both the US and the UK, for instance, the continuing dominance of neoliberal ideology in social policy has meant that the latter has become increasingly harsh and residual, service users have been increasingly marginalized and disempowered and the two positions have become increasingly polarized. It has become increasingly difficult to maintain the sense that formal arrangements for participation can offer people a real say as public services and welfare provision has been increasingly cut back.

This has had a number of expressions, associated with developments on the part of both state/service system policies and approaches to involvement and those of citizens/ service users. We can look at each of these in turn, beginning with prevailing approaches based on neoliberal ideology. The UK offers an advanced case study of this.

\section{Reaction - from the service system}

Since the economic crisis of 2007-2008, public policy in the UK has been based on the idea of 'austerity' with sharp cuts made in public services and the implementation of so-called 'welfare reform', based on reducing access to and expenditure on welfare benefits, notably to poor, unemployed and disabled people. The harsh and extreme effects of such policies have been evidenced and highlighted by service users themselves and their user led organisations, their allies and academic research. So far this has had little effect in changing such policy (O'Hara 2014; Garthwaite 2016; Beresford 2016), which can be seen as much more part of an underpinning neoliberal agenda, as a response to economic difficulties. Despite the continuing governmental rhetoric extolling user choice and involvement, little if any notice has been taken of the strong and wide-ranging 
criticisms that there have been of such welfare reform policy, not least from service users themselves.

At the same time, disabled people's and other service users' organisations are face rising insecurity, are having an increasing struggle to continue and, many are closing down. They have long had inferior access to funding and other resources compared with traditional charities and voluntary organisations and this situation now seems to have worsened as funding has declined. Thus the latest evidence worryingly highlights both that survivor led organisations in the UK, are seriously declining in numbers, while the same pattern is apparent for ULOs more generally. While some new organisations are emerging, others are having to close or downsize. Over an 18 months period from 2015, more than a quarter of survivor led organisations in England had closed down (Yiannoullou 2018). So instead of progress being made towards services becoming more democratic, access to their support is increasingly restricted and their control role highlighted.

At the same time, mainstream policy and provision has increasingly been framed in terms of ideas and values inspired by and associated with service users and their quest for more say and control over their lives. Three key expressions of this are the reframing of policy and provision in terms of:

- self-management;

- peer support;

- recovery.

Yet each can actually be seen as the incorporation and co-option of ideas originating with service users and their subversion and realignment with neoliberal values and ideas. Thus self-management in mental health discourse and policy is not so about 'managing' in the sense of being able to regain personal control, but 'managing' in the 'new managerialist' sense that has come to permeate modern neoliberal social policy. 'Peer support' has been institutionalised into the role of 'peer support worker'. Instead of being based on an alternative user-led paradigm challenging psychiatry, such roles seem more and more to be framed as lower paid ancillary jobs incorporated into the prevailing values, ideas and structures of psychiatry. They occupy an increasingly ambiguous role as an acceptable face of the system for patients entering it, with minimal say and control over it or their role (Penny, Prescott 2016; Penny 2018). The idea of 'recovery' has been advanced in official policy as challenging the historic writing-off of mental health service users as permanently damaged, dependent and unreclaimable. But it is actually tied to a bio-medical model. It does not take long to work out that if someone is seen as 'recovered' then the support they have received may also be seen as no longer necessary. The reality has been that the idea of recovery has been bound up in neoliberal psychiatric thinking with 'restoring' or pressurising service users to employment as a primary focus (Gadsby 2015).

The reality is that while the policy atmosphere is one that seems sensitive to and supportive of user involvement and developments associated with it, there is little effective 
support for it; policy's direction of travel is in many ways antagonistic to it and there seem to be fewer resources made available to support it.

\section{Renewal - from service users}

While years of neoliberalism have certainly imposed limits on the development of user involvement and citizen participation, as well as on the rights and say of people as service users, it would be wrong to assume that it has killed progress. Indeed, what we can see is an increasing focus and indeed in some sense, a strengthening of activity. Thus welfare service users in the UK, while coming under particular attack from welfare reform policies, have been in the lead in challenging such developments, often providing both the evidence and the impetus for challenging them (Beresford 2012). Thus while experiencing much suffering in recent years, service users and their organisations have extended both their critiques and their action in relation to social work and other policies and services. Some key areas of activity include:

- Widening involvement and campaigning, challenging exclusions.

- Involvement in professional and occupational training.

- Involvement in research and knowledge production.

- The development of 'Mad Studies'.

- And in this last part of the discussion, I want to focus on these particular areas of activity.

\section{Widening involvement and campaigning, challenging exclusions}

Beginning with the disabled people's movement, service users, have long highlighted that conventional approaches to participation tend to exclude many groups and individuals. While they have worked hard to make people's involvement more accessible and inclusive, highlighting environmental, communication and cultural barriers, these continue to operate. The history of the UK disabled people's movement is one that has increasingly highlighted and challenged exclusions and discriminations. Most recently people with long term conditions have asserted their particular difficulties and right to be involved. Service users themselves have also highlighted the ways in which social media and networking can challenge such barriers (as well as reinforcing them). A study by the user led organisation and network Shaping Our lives, has evidenced the way in which diverse involvement is restricted. It identified big barriers in the way of five major groups, but also strategies to overcome them. Such groups of service users are excluded according to:

- Equality issues; on the basis of gender, sexuality, ethnicity, class, culture, belief, age, disability and so on.

- Where they live; if they are homeless, travellers, in prison, in welfare institutions, refugees and so on. 
- Communicating differently; they do not speak the prevailing language, it is not their first language, they are deaf and used sign language, etc.

- The nature of their impairments; where these are seen as too complex or severe to mean they could or would want to contribute.

- Where they are seen as unwanted voices; they do not necessarily say what authorities wanted to hear, are seen as a problem, disruptive etc. These includes neuro-diverse people and people affected by dementia (Beresford, 2013).

The large scale operation of these barriers means that the knowledges of many service users continue routinely to be excluded from discussions and developments, although we now have the evidence to overcome such barriers.

\section{Involvement in professional and occupational training}

Involving service users (and family carers) in professional and occupational education and training has long been seen as one of the most effective ways of improving the nature and culture of social work and other helping practice and services. PowerUs, a partnership of social work educators and service users and their organisations, which already involves twelve countries, within and beyond Europe, has sought to develop methods of mutual learning in order to change social work practice to be more effective in supporting the empowerment of marginalized and discriminated groups in society (http://powerus.eu). The 'gap-mending' process began at Lund University in Sweden in 2005 as a method of teaching that brought service users and social work students together to learn together on as equal terms as possible. The idea is about bridging divisions between service users and social work students in their learning through new approaches to user involvement. It also represents an alternative approach to the increasing emphasis under neoliberal politics on graduate and elite/fast track approaches to social work education, giving value to 'user knowledge', rather than just academic qualifications. People 'meet as people' on gap-mending courses; service users get formal recognition and accreditation for the skills they offer as well as the skills they gain. Social work students who also have lived experience' as service users are valued for it and can share it if they wish to. Perhaps most important is the building of trust and understanding between service users and would-be social workers which is likely to have a profound effect on future relations and practice between them (http://powerus.eu/news/the-photo-exhibition-experiences-matter/). Key gaps that the approach has identified include between, needs and resources; the priority social work demands and the priority it is given; service users and providers, 'expert' and experiential knowledge; social work education and practice - and researchers and research subjects (Askheim, Beresford, Heule 2017).

\section{Involvement in research and knowledge production}

Research has been the site of one of the most complex and contentious struggles between service users and neoliberal ideology. Its origins can be seen to lie in the struggles first 
of feminists and then disabled people - to challenge what some have called 'epistemic violence' and exclusion, from the 1970 s and regain control over their 'experiential' knowledge - the knowledge that comes out of people's individual and collective lived experience. The UK disabled people's movement condemned existing disability research in the 1970s as biased and on the side of the service system that controlled their lives. To counter this, they developed their own 'emancipatory disability research' which prioritised the equalising of research relationships, the empowerment of disabled people and the achievement of social change to support their rights and needs (Barnes, Harrison, Mort, Shardlow 1999). The survivor movement developed survivor research along the same lines. At the same time existing research structures began to show an increasing interest in involving research subjects in research process, framed in the UK in terms of 'public, patient involvement' or PPI. For some time there has seemed to be some convergence between these two developments. But increasingly tensions have emerged between the consumerist/managerialist aims of such involvement in much mainstream psychiatric and other health research under neoliberalism and the emancipatory goals of mental health service users/survivors (Rose, Carr, Beresford 2018). Thus PPI is coming under increasing attack as 'centered on a construction of the abstract, rational, compliant, and self-managing patient' under neoliberalism (Madden, Speed 2017).

\section{The development of 'Mad Studies'}

Finally, I want to turn to the emergence of 'Mad Studies', because it brings together many of the progressive aims and aspirations of service users in relation to social work and other areas of professional activity and highlights the possibility of building alliances between different stakeholders to achieve these aims. Mad Studies is a field of study and action relating to what are more often called 'mental health' policy, services and service users, which has its origins in Canada and which is now fast gaining interest internationally (LeFrancois, Menzies, Reaume 2013). What generally seems to define the key elements of mad studies is that:

First, it is definitely divorcing us and itself from a simplistic biomedical model, making possible a necessary rupture from it. It allows other understandings and disciplines to come into it instead of solely medical dominance - sociology, anthropology, social work, cultural studies, feminist, queer studies, disability studies, history, everything.

Second is the value and emphasis it places on first person knowledge - centring on the first person knowledge of everyone, not just those psychiatrised. If you want to talk about yourself, then you have a right to, it is ok to include yourself. This is positioned/ situated research - you can't just be talking from nowhere, as if you had no place in the proceedings - as it has been in psychiatry.

And finally of course, Mad Studies treats survivors' first hand knowledge with equality. But Mad Studies values and has a place for all our first hand experiential knowledge; that's why such a wide range of roles and standpoints can contribute equally to Mad Studies if they are happy to sign up to its core principles. It isn't only us as survivors/ 
mental health service users, but allies, professionals, researchers, loved ones, and so on, This is a venture we can all work for together in alliance. So it includes the experiential knowledge of service users, the practice knowledge/wisdom of workers and the knowledge from those offering support, of family carers as important bases for future research and development (Beresford, Russo 2016).

\section{Conclusion}

The aim of this discussion has been to put the praxis of participation and user involvement in their broader context; to draw on the pioneering work of social work and social workers in taking it forward and to consider the realities and possibilities of user involvement in social work internationally for the future. In making this journey it is difficult not to be made very aware of the many obstacles in the way of advancing such participation, especially in times when neoliberal ideology still seems both to be on the ascendancy globally and, to have a great capacity to undermine and neutralise pressures for participation. At the same time, we can see that thinking, practice and policy around user involvement have developed in ways and to an extent that could not have been envisaged a generation or even twenty years ago. They have had enormous implications for policy, provision, research and the lives of service users. They have demarcated progressive ways forward for social work and other helping professions. We are in the very midst of change - more advanced in some settings, some nations and in some politics than others. But nonetheless it would be very difficult to argue that social work and service users have not already benefitted from the progress already achieved and that directing our efforts to advance such progress, whatever the state of play in our own situation, is not likely to be an important and worthwhile activity and goal.

\section{References}

Abel-Smith B., Townsend P. (1965). The poor and the poorest. A new analysis of the Ministry of Labour's family expenditure surveys of 1953-54 and 1960. "LSE Occasional Papers on Social Administration" 17, G. Bell and Sons, London.

Arnstein S.R. (1969). A ladder of citizen participation. "Journal of the American Institute of Planning" (JAIP), 35 (4): 216-224.

Askheim O.P., Beresford P., Heule C. (2017). 'Mend the gap' - strategies for user involvement in social work education. "Social Work Education", 36 (2), 17: 128-140.

Atkinson A.B. (1983). The Economics Of Inequality. Clarendon Press, Oxford University Press, Oxford.

Barnes M., Harrison S., Mort M., Shardlow P. (1999). Unequal Partners: User Groups and Community Care. The Policy Press, Bristol. 
Beresford P. (2012). From 'vulnerable' to vanguard: Challenging the coalition, in: S. Davison, J. Rutherford (eds.), Welfare Reform: The Dread of Things to Come. "Soundings". Lawrence Wishart, London: 66-77.

Beresford P. (2013). Beyond the Usual Suspects: Towards Inclusive User Involvement - Research Report. Shaping Our Lives, London.

Beresford P. (2016). All Our Welfare: Towards Participatory Social Policy. Policy Press, Bristol. Beresford P., Beresford S. (1984). A Say in the Future: Planning, Participation and Meeting Social Need, $2^{\text {nd }}$ ed. Battersea Community Action, London.

Beresford P., Croft S. (1987). Are we really listening?: The client speaks, by John Meyer and Noel Timms (1970), in: T. Philpot (ed.), On Second Thoughts: Reassessments of the Literature of Social Work. Community Care/Reed Publishing, London: 50-55.

Beresford P., Croft S. (1993). Citizen Involvement: A Practical Guide for Change. Macmillan, Basingstoke.

Beresford P., Croft S. (2012). User Controlled Research: Scoping Review. NHS National Institute for Health Research (NIHR) School for Social Care Research, London School of Economics, London.

Beresford P., Russo J. (2016). Supporting the sustainability of mad studies and preventing its co-option. "Disability \& Society", 31 (2): 270-274.

Campbell J., Oliver M. (1996). Disability Politics: Understanding Our Past, Changing Our Future. Routledge, London.

CDP (1977). Gilding The Ghetto: The State and the Poverty Experiments. Community Development Inter-Project Editorial Team, location not known.

Charlton J.I. (1998). Nothing About Us Without Us: Disability, Oppression and Empowerment. University of California Press, California.

Craig G., Mayo M., Popple K., Shaw M., Taylor M. (eds.) (2011). The Community Development Reader: History, Themes and Issues. Policy Press, Bristol.

Dennis N. (1972). People And Planning: The Sociology of Housing in Sunderland. Faber and Faber, London.

Faulkner A. (2010). Changing Our Worlds: Examples of User Controlled Research in Action. NIHR INVOLVE, Eastleigh.

Gadsby J. (2015). The Recovery Star Meets The Unrecovery Star, Critical Mental Health Nurses' Network, October 19 ${ }^{\text {th }}$ CMH Nursing; https://criticalmhnursing.org/2015/10/19/the-recovery-star-meets-the-unrecovery-star/ (accessed: 06.01.2018).

Garthwaite K. (2016). Hunger Pains: Life Inside Foodbank Britain. Policy Press, Bristol.

Halsey A.H. (ed.) (1972). Trends In British Society Since 1900: A Guide to the Changing Social Structure of Britain. Palgrave MacMillan, Basingstoke.

Jordan T., Lent A. (eds.) (1999). Storming The Millennium: The New Politics of Change. Lawrence and Wishart, London.

Ledwith M. (2016). Community Development in Action: Putting Friere into Practice. Policy Press, Bristol.

Le Francois B.A., Menzies R., Reaume G. (eds.) (2013). Mad Matters: A Critical Reader in Canadian Mad Studies. Canadian Scholars Press, Toronto. 
Lister R. (2003). Citizenship: Feminist Perspectives, $2^{\text {nd }}$ ed. Palgrave/Macmillan, Basingstoke.

Loney M. (1983). Community Against Government: British Community Development Project, 1968-78 (Studies in Social Policy and Welfare). Heinemann Educational Books, London.

Madden M., Speed E. (2017). Beware zombies and unicorns: Toward critical patient and public involvement in health research in a neoliberal context. "Frontiers In Sociology", 2 (7), doi 10.3389/soc.2017.00007.

Marshall T.H. (1950). Citizenship and Social Class and Other Essays. Cambridge University Press, Cambridge.

O'Hara M. (2014). Austerity Bites: A Journey to the Sharp and of Cuts in the UK. Policy Press, Bristol.

Oliver M. (1983). Social Work and Disabled People. Macmillan, Basingstoke.

Oliver M. (1990). The Politics Of Disablement. Macmillan and St Martin's Press, Basingstoke.

Penny D., Prescott L. (2016). The co-optation of survivor knowledge: The danger of substituted values and voice, in: J. Russo, A. Sweeney (eds.), Searching For a Rose Garden; Challenging Psychiatry, Fostering Mad Studies. PCCS Books, Ross-on-Wye: 35-45.

Penny D. (2018). Who gets To define 'peer support'?, in: Mad in America, February $10^{\text {th }}$; https:// www.madinamerica.com/2018/02/who-gets-to-define-peer-support/ (accessed: 06.01.2018).

Rose D., Carr S., Beresford P. (2018). Widening cross-disciplinary research for mental health: What is missing from the research councils' UK Mental Health Agenda?. "Current Issues, Disability \& Society”, 33 (3); https://doi.org/10.1080/09687599.2018.1423907 (accessed: 06.01.2018).

SCIE (2009). Building User and Carer Involvement in Social Work Education, at a Glance 19, Social Care Institute for Excellence, London; https://www.scie.org.uk/publications/ataglance/ ataglance19.asp (accessed: 06.01.2018).

Titmuss R.M. (1968). Commitment to Welfare. George Allen and Unwin, London.

Todd M.J., Taylor G. (eds.) (2004). Democracy and Participation: Popular Protest and New Social Movements. Merlin Press: London.

Warren J. (2007). Service User and Carer Participation in Social Work. Transforming Social Work Practice series, Exeter, Learning Matters.

Yiannoullou S. (2018). Chief Executive, National Survivor User Network, reporting on NSUN survey, Personal Communication, $13^{\text {th }}$ March. 